\title{
Gut microbiota: Enemy inside the obese
}

Bedanta Roy

\section{Corresponding author:}

Dr. Bedanta Roy, Senior Lecturer, Department of Physiology, Faculty of Medicine, Quest International University Perak (QIUP) City Campus, No.227, Plaza Teh Teng Seng (Level 2), Jalan Raja Permaisuri Bainun, 30250 Ipoh, Perak Darul Ridzuan, Malaysia.

Email: bedanta.roy@gmail.com $\underline{\text { ORCID }}$

\section{Information about the article:}

Published online: Oct. 10, 2018

\section{Cite this article:}

Roy B. Gut microbiota: Enemy inside the obese. Journal of Biomedical Sciences. 2017;4(2):9-10.

\section{Publisher}

Nepal Health Research and Welfare Society, Jorpati, Kathmandu, Nepal eISSN 2382-5545

(C) The Author(s). 2018

Content licensing: CC BY 4.0

\section{EDITORIAL}

Obesity-associated disorders increasing at an alarming rate. The most prominent causes are the sedentary lifestyle and increased consumption of food. Environmental, genetic factors and gut microbiota plays a complex role in the development of metabolic disorders. [1, 2] The human body contains a large number of microorganisms, which invade the intestinal tract during parturition (maternal vaginal microbes), by the maternal skin, and during breastfeeding. [3] Gut microbiota can be classified into four major phyla Firmicutes, Bacteroidetes, Actinobacteria, and Proteobacteria. The large intestine is the main host for gut microbiota; over $10^{11}$ bacteria are present in each gram of intestinal content. Gut microbiota plays a vital physiological role, which includes digestion, synthesis of new biomolecules and metabolism amongst others. Gut microbiota is linked to increase in dietary energy production, regulation of fatty acid tissue composition and low-grade inflammation, triggering obesity. [4]

Researches in the recent years revealed the close association of gut microbiota and obesity. The difference between gut microbiota of obese and lean mice is well established. A shift of bacteria from Bacteroidetes phyla towards Firmicutes phyla is closely related with augmented energy absorption from diet and initiates low-grade inflammation. [5] Colonic fermentation of digestive products like dietary fiber, proteins by gut microbiota produces short-chain fatty acids (SFCAs). Cecal and fecal level of this biomolecule is found more in genetically obese ob/ob mice and obese individuals connected with reduced colonic absorption. [6] SCFA act as signaling molecules in liver and muscle activates AMP-activated protein kinase (AMPK) cholesterol, lipid, and glucose metabolism by a variety of receptors namely peroxisome proliferator-activated receptorgamma coactivator 1 alpha (PGC-1 $\alpha$ ), Peroxisome proliferator-activated receptor gamma (PPAR $\gamma$ ), and Liver X receptors (LXR). [7] This activates low-grade inflammatory response, which leads to obesity. Higher level of lipopolysaccharides (LPS) also increases fat intake. Toll-like receptors (TLRs) and nuclear factor kappa (NF-kB) are the key factors for the genesis of proinflammatory cytokines by a cascade pathway. [8] The production of LPS activates this pathway. Interestingly LPS is found in the outer membrane of Gram-negative bacteria produced in the gut. Gut microbiota also regulates bile acids and cholesterol metabolism by upregulating several transcription factors connected with 
nutritional-induced inflammation, absorption of lipid and lipogenesis. [9]

Evidence from emerging research on energy homeostasis and inflammation highlights gut microbiota as a crucial factor in obesity. Prebiotic and probiotic bacteria can be utilized as a treatment option for metabolic diseases in near future.

\section{Abbreviations}

AMP-activated protein kinase (AMPK), lipopolysaccharides (LPS), liver X receptors (LXR), nuclear factor kappa (NF-kB), peroxisome proliferator-activated receptor gamma (PPAR $\gamma)$, peroxisome proliferatoractivated receptor-gamma coactivator 1 alpha (PGC-1 $\alpha$ ), short-chain fatty acids (SFCAs), toll-like receptors (TLRs)

\section{Competing interests}

None declared.

\section{Publisher's Note}

NHRWS remains neutral with regard to jurisdictional claims in published maps and institutional affiliations.

The publisher shall not be legally responsible for any types of loss, actions, claims, proceedings, demand or costs or damages whatsoever or howsoever caused arising directly or indirectly in connection with or arising out of the use of this material.

\section{References}

1. Cox AJ, West NP, Cripps AW. Obesity, inflammation, and the gut microbiota. Lancet Diabetes Endocrinol. 2015;3:207-215. DOI: https://doi.org/10.1016/S2213-8587(14)70134-2

2. Roy B, Ghosh S, Sathain B, Banerjee I. Genetic basis of obesity: a review. Journal Of Biomedical Sciences, 2018; 3(2):24-28. DOI: https://doi.org/10.3126/jbs.v3i2.18921

3. Makino H, Kushiro A, Ishikawa E, Kubota H, Gawad A, Sakai T et al. Mother-to-infant transmission of intestinal bifidobacterial strains has an impact on the early development of vaginally delivered infant's microbiota. PLoS One. 2013;8:e78331. DOI: https://doi.org/10.1371/journal.pone.0078331

4. Kallus SJ, Brandt LJ. The intestinal microbiota and obesity. J Clin Gastroenterol. 2012;46:1624.

DOI: https://doi.org/10.1097/MCG.0b013e31823711f $\underline{\mathrm{d}}$

5. Turnbaugh PJ, Ley RE, Mahowald MA, Magrini V, Mardis ER, Gordon JI. An obesityassociated gut microbiome with increased capacity for energy harvest. Nature.
2006;444:1027-1031.

DOI:

https://doi.org/10.1038/nature05414

6. Fernandes J, Su W, Rahat-Rozenbloom S, Wolever TM, Comelli EM. Adiposity, gut microbiota and faecal short chain fatty acids are linked in adult humans. Nutr Diabetes. 2014;4:e121. DOI: https://doi.org/10.1038/nutd.2014.23

7. den Besten $G$, van Eunen $K$, Groen AK, Venema K, Reijngoud DJ, Bakker BM. The role of short-chain fatty acids in the interplay between diet, gut microbiota, and host energy metabolism. J Lipid Res. 2013;54(9):2325-40. DOI: https://doi.org/10.1194/jlr.R036012

8. Ye D, Li FY, Lam KS, Li H, Jia W, Wang Y et al. Toll-like receptor-4 mediates obesityinduced non-alcoholic steatohepatitis through activation of X-box binding protein-1 in mice. Gut. 2012;61:1058-1067. DOI: https://doi.org/10.1136/gutjnl-2011-300269

9. Conterno L, Fava F, Viola R, Tuohy KM. Obesity and the gut microbiota: does upregulating colonic fermentation protect against obesity and metabolic disease? Genes Nutr. 2011;6:241-260.

DOI: https://doi.org/10.1007/s12263-011-0230-1 